\title{
Chemical Composition and Functional Properties of Malted Corn Flours
}

\author{
Maria Victória E. Grossmann*1, José Marcos G.Mandarino ${ }^{2}$ and Márcia Cristina Yabu ${ }^{1}$ \\ ${ }^{1}$ Departamento de Tecnologia de Alimentos e Medicamentos, Universidade Estadual de Londrina. C.P. 6001 - CEP \\ 86051-970 - Londrina - PR - Brazil \\ ${ }^{2}$ EMBRAPA-CNPSo. - C.P. 1061 - CEP 86001-970 - Londrina, PR - Brazil
}

\begin{abstract}
Flours with different physicochemical and functional properties were obtained from malted corn. Response surface methodology (RSM) was used to study the effects of malting time (1,3, 5 days), malting temperature $\left(20,25,30^{\circ} \mathrm{C}\right)$ and gibberelic acid concentration $(0.0 ; 0.5 ; 1.0 \%)$ on these properties. The chemical composition and paste viscosity of flours were significantly affected by malting time and temperature, while water solubility index (WSI) and water absorption index (WAI) varied only with malting time. Gibberelic acid did not significantly influenced any of the studied properties. Germination at $20-25^{\circ} \mathrm{C}$ for 3 days was recomended to obtain corn flour with high WAI, low viscosity and medium WSI, without excessive loss of proteins.
\end{abstract}

Key words: malting, corn flour, functional properties

\section{INTRODUCTION}

Corn flour is an important food ingredient, mainly in Latin America countries. Its industrial and food uses would increase if apropriate applications were developed. One way to increase uses of raw materials is to promote functional modifications. As new food systems are developed, new ingredient modifications and or new techniques for these modifications would be needed.

Malting process is know as a way to promote changes in the biochemical, sensorial and nutritional characteristics of cereal grains (Lorenz,1980; Colmenares de Ruiz \& Bressani,1990; Mora-Escobedo et al, 1991).

Some researchers have proposed the use of malting as a process for weaning food production, based on reduction in viscosity and increase in the nutrient density in malted flour pastes or beverages (Mosha,1983; Atwell et $a l, 1988)$.
The objective of this study was to evaluate the functional and physicochemical characteristics of corn flours modified by germination.

\section{MATERIAL AND METHODS}

\section{Material}

Corn (double hybrid AG64A) used in the experiments was provided by Sementes Agroceres, Pato Branco - PR, Brazil.

\section{Malting Process}

Sprouted corn samples were prepared according to a partial modification of Sing \& Bains (1984) procedure. Corn kernels were surface sterilized by soaking in a $2 \%$ sodium hypochlorite solution for $10 \mathrm{~min}$ at room temperature and then rinsed several times with distilled water. Samples were soaked in distilled water at $20^{\circ} \mathrm{C}$ for 24 hours to attain $40 \%$ moisture. Different concentrations of gibberellic acid were added to the soaking water according to the experimental design. After rinsing with distilled water, samples were placed in a germinator $(100 \%$ $\mathrm{RH})$. Time and temperature of malting also varied with the experimental design. Malted

\footnotetext{
*Author for correspondence
} 
corn was shelled, degerminated by hand, and then dried in air oven $\left(50^{\circ} \mathrm{C}\right)$ to $12 \%$ moisture content. Samples were placed in sealed plastic containers and stored at room temperature until use.

\section{Milling}

Control and sprouted samples were ground in laboratory mills. First in a Tecnal mill (model TE 090, Tecnal, São Paulo, Brazil), equipped with a $0.5 \mathrm{~mm}$ screen, and then in an Alpine mill (model 63C, Alpine Augsburg) with a $0.15 \mathrm{~mm}$ screen.

\section{Corn Flours Chemical Composition}

Moisture, ash, nitrogen, lipids and reducing sugars contents were determined according to AACC (1983) approved methods. All analysis were made in triplicate.

\section{Corn Flours Functional Properties}

Water absorption index (WAI) and water solubility index (WSI) were calculated as described by Anderson et al (1969).

Pasting properties were determined on a Brabender Visco-Amylograph (Brabender Instruments, South Hackensak, NY), using a standard cartridge of $750 \mathrm{cmg}$ and a rotation speed of $75 \mathrm{rpm}$. Corn flour samples (50g d.b.) were dispersed in $450 \mathrm{ml}$ distilled water and transferred to the test bowl. Suspensions were heated from 30 to $95^{\circ} \mathrm{C}$ at a rate of $1.5^{\circ} \mathrm{C}$ per minute, and then cooked at $95^{\circ} \mathrm{C}$, for $20 \mathrm{~min}$. The cooling cycle was carried out by lowering the temperature at the same rate down to $30^{\circ} \mathrm{C}$. Paste characteristics were expressed as peak viscosity and viscosity upon reaching $30^{\circ} \mathrm{C}$ after cooling.

\section{Experimental Design and Statistical Analysis} An incomplete factorial $\left(3^{3}\right)$ design (Box \& Benken,1960) was used with selected variables shown in Table 1. These independent variables were chosen because they influenced malting process (gibberelic acid induces synthesis and release of $\alpha$-amylase) and their levels were based on literature information (Sing \& Bains,1984). For statistical analysis, the three levels of each variable were coded as $-1,0$ and +1. A SAS (1985) statistical program was used to analyse the data to obtain second order response surface models, which had linear, quadratic and all the interaction terms for the three independent variables. Dependent variables were protein, ash, lipids, reducing sugars, WSI, WAI, peak viscosity and cold viscosity. Independent variables, which were found significant at $\mathrm{P}<0.05$ in the full models were retained in simplified models. The best final model was determined following the stepwise regression procedure. Surface plots were drawn using the Statistica (StatSoft, Oklahoma) computer software to show the effect of two independent variables while the other was held constant at zero level.

\section{RESULTS AND DISCUSSION}

The experimental data for all properties analyzed, including the control sample (non germinated corn), are presented in Table I. Multiple regression analysis resulted in significant full models $(\mathrm{P}<0.05)$ for all dependent variables, with high $\mathrm{R}^{2}(>90 \%)$ values (data not shown)

In the models for lipids, reducing sugars, peak viscosity and cold viscosity the lack of fit was significant $(\mathrm{p}<0.01)$. However, it does not interfere on the model validity since the mean square for experimental error takes an extremely low values. This way, the test of significance for lack of fit could be considered irrelevant (Waszczynskyj et al, 1981). Analysis of variance showed that time and temperature seemed to influence the modification caused by germination being time the most important. Only WSI was affected by gibberelic acid concentrations $(p<0.05)$ and its interaction with time was also significant for peak viscosity $(\mathrm{p}<0.05)$. 
Table 1. Experimental Design for Germination and Results for Response Variables.

\begin{tabular}{|c|c|c|c|c|c|c|c|c|c|c|c|}
\hline \multicolumn{4}{|c|}{ Independent Variables } & \multicolumn{8}{|c|}{ Dependent Variables } \\
\hline $\begin{array}{c}\text { Run } \\
\mathrm{n}^{\mathrm{o}} .\end{array}$ & $\begin{array}{l}\text { Time } \\
\text { (d) }\end{array}$ & $\begin{array}{c}\text { Temperature } \\
\left({ }^{\circ} \mathrm{C}\right)\end{array}$ & $\begin{array}{c}\text { Gibberelic } \\
\text { Acid (ppm) }\end{array}$ & $\begin{array}{l}\text { Protein } \\
(\%)^{\mathrm{a}}\end{array}$ & $\begin{array}{l}\text { Ash } \\
(\%)^{\mathrm{a}}\end{array}$ & $\begin{array}{r}\text { Lipids } \\
(\%)^{\mathrm{a}}\end{array}$ & $\begin{array}{l}\text { Red. } \\
\text { Sugars } \\
(\%)^{\mathrm{a}}\end{array}$ & $\begin{array}{l}\text { WSI } \\
(\%)\end{array}$ & WAI & $\begin{array}{c}\text { Peak } \\
\text { Viscosity } \\
(\mathrm{AU})\end{array}$ & $\begin{array}{c}\text { Cold } \\
\text { Viscosit } \\
\text { (AU) }\end{array}$ \\
\hline 1 & 1 & 20 & 0.5 & 7.3 & 0.34 & 0.64 & 0.46 & 2.94 & 1.68 & 700 & 2140 \\
\hline 2 & 5 & 20 & 0.5 & 5.6 & 0.22 & 0.33 & 4.74 & 10.57 & 1.20 & 20 & 10 \\
\hline 3 & 1 & 30 & 0.5 & 6.6 & 0.27 & 0.31 & 2.50 & 7.71 & 1.45 & 360 & 700 \\
\hline 4 & 5 & 30 & 0.5 & 4.1 & 0.27 & 0.39 & 8.22 & 14.06 & 1.24 & 40 & 10 \\
\hline 5 & 1 & 25 & 0.0 & 7.2 & 0.28 & 0.42 & 1.11 & 6.65 & 1.40 & 680 & 1820 \\
\hline 6 & 5 & 25 & 0.0 & 4.0 & 0.27 & 0.27 & 9.39 & 16.04 & 1.13 & 10 & 10 \\
\hline 7 & 1 & 25 & 1.0 & 7.4 & 0.31 & 0.49 & 1.35 & 6.50 & 1.31 & 320 & 780 \\
\hline 8 & 5 & 25 & 1.0 & 4.7 & 0.23 & 0.22 & 7.02 & 12.48 & 1.24 & 20 & 10 \\
\hline 9 & 3 & 20 & 0.0 & 6.5 & 0.24 & 0.52 & 3.55 & 8.62 & 1.26 & 100 & 30 \\
\hline 10 & 3 & 30 & 0.0 & 5.3 & 0.27 & 0.49 & 6.28 & 12.53 & 1.08 & 20 & 10 \\
\hline 11 & 3 & 20 & 1.0 & 6.3 & 0.22 & 0.72 & 3.68 & 8.94 & 1.12 & 100 & 20 \\
\hline 12 & 3 & 30 & 1.0 & 5.3 & 0.21 & 0.77 & 5.98 & 10.39 & 1.10 & 40 & 10 \\
\hline 13 & 3 & 25 & 0.5 & 5.5 & 0.24 & 0.76 & 5.33 & 11.22 & 1.16 & 20 & 10 \\
\hline 14 & 3 & 25 & 0.5 & 5.4 & 0.22 & 0.77 & 5.37 & 11.91 & 1.13 & 20 & 10 \\
\hline 15 & 3 & 25 & 0.5 & 5.6 & 0.22 & 0.76 & 5.24 & 10.74 & 1.22 & 20 & 10 \\
\hline \multicolumn{4}{|c|}{ Control (non germinated corn) } & 7.0 & 0.19 & 0.95 & 0.16 & 2.66 & 2.24 & 700 & 1600 \\
\hline
\end{tabular}

- Dry basis

AU - Amylographic Units

WSI - Water solubility index $(\%)$

WAI - Water absorption index (g gel/g sample)

Stepwise regression analysis resulted in reduced models (Table II) that contained the significant variables and were used to generate surface plots for the studied responses.

\section{Chemical Composition of Flours}

The germination increased the ash content in the corn flours (Fig. 1a). This increase was lower at $20^{\circ} \mathrm{C}$ and higher at $25-30^{\circ} \mathrm{C}$.

Protein content of malted flours decreased when time and germination temperature increased (Fig. 1b). Similar results were obtained by other authors (Tsai et al, 1975; Lukov \& Bushuk,1984) which attributed this fact to the migration of endosperm aminoacids to the growing plant. In order to avoid excessive protein losses, it should be recommended not to use periods of germination longer than three days. Leaching of soluble proteins may have occurred during soaking and also explain the protein decrease.

The lipids content reached a maximum $(0.69 \%)$ after three days of germination, at $21^{\circ} \mathrm{C}$ (Fig. $1 \mathrm{c})$. When time and temperature increased, or decreased, the lipids content decreased to a value always lower than the control (non germinated corn). This decrease could be explained by the migration of lipids to the growing plant. On other hand the increase in ash content seemed to be an apparent increase, caused by losses in dry matter as a consequence of respiration and nutrient migration (Lorenz,1980). 
Table 2. Best prediction models for response variables ${ }^{\mathrm{a}}$.

\begin{tabular}{|c|c|c|}
\hline Dependent variable & Prediction equation & $\mathrm{R}^{2}$ \\
\hline Protein & $y=5.84-1.29 x_{1}-0.56 x_{2}$ & 0.92 \\
\hline Ash & $\mathrm{y}=0.23-0.03 \mathrm{x}_{1}+0.04 \mathrm{x}_{1}^{2}+0.03 \mathrm{x}_{1} \mathrm{x}_{2}$ & 0.80 \\
\hline Lipids & $y=0.68-0.08 x_{1}-0.30 x_{1}^{2}$ & 0.70 \\
\hline Reducing sugars & $\mathrm{y}=4.68+2.99 \mathrm{x}_{1}+1.32 \mathrm{x}_{2}$ & 0.91 \\
\hline Water solubility index & $y=11.42+3.67 x_{1}+1.70 x_{2}-0.69 x_{3}-0.10 x_{1}^{2}-1.40 x_{2}^{2}$ & 0.95 \\
\hline Water absorption index & $\mathrm{y}=1.15-0.13 \mathrm{x}_{1}+0.18 \mathrm{x}_{1}^{2}$ & 0.70 \\
\hline Peak viscosity & $y=46-246 x_{1}-57 x_{2}+223 x_{1}^{2}+90 x_{1} x_{2}+90 x_{1} x_{3}$ & 0.95 \\
\hline Cold viscosity & $y=14-675 x_{1}+671 x_{1}^{2}+360 x_{1} x_{2}$ & 0.84 \\
\hline
\end{tabular}

${ }^{\mathrm{a}} \mathrm{x}_{1}=$ time $; \mathrm{x}_{2}=$ temperature; $\mathrm{x}_{3}=$ gibberelic acid concentration (coded values)

There was an increase in the reducing sugars content of the flours with the increase in time and temperature (Fig. 1d), as a consequence of enzymatic degradation of the starch (Lukov \& Bushuk,1984; Sing \& Bains,1984).

\section{Functional Properties of Flours}

WSI is an important characteristic for cereal flours used in beverages preparation. With the increase in time and temperature of germination there was an increase in WSI (Fig. 2a). The maximum value was $13.29 \%$, which represented an increase of $400 \%$ in relation to the control. To reach this degree of solubility there was no need to use the variables at their highest levels, instead $25^{\circ} \mathrm{C} / 4$ days or $22.5^{\circ} \mathrm{C} / 5$ days might be used. WSI increase in flours as a consequence of germination could be explained by the formation of lower molecular weight compounds due to the activity of amylases and proteases (Lorenz,1980; Lukov \& Bushuk,1984). 

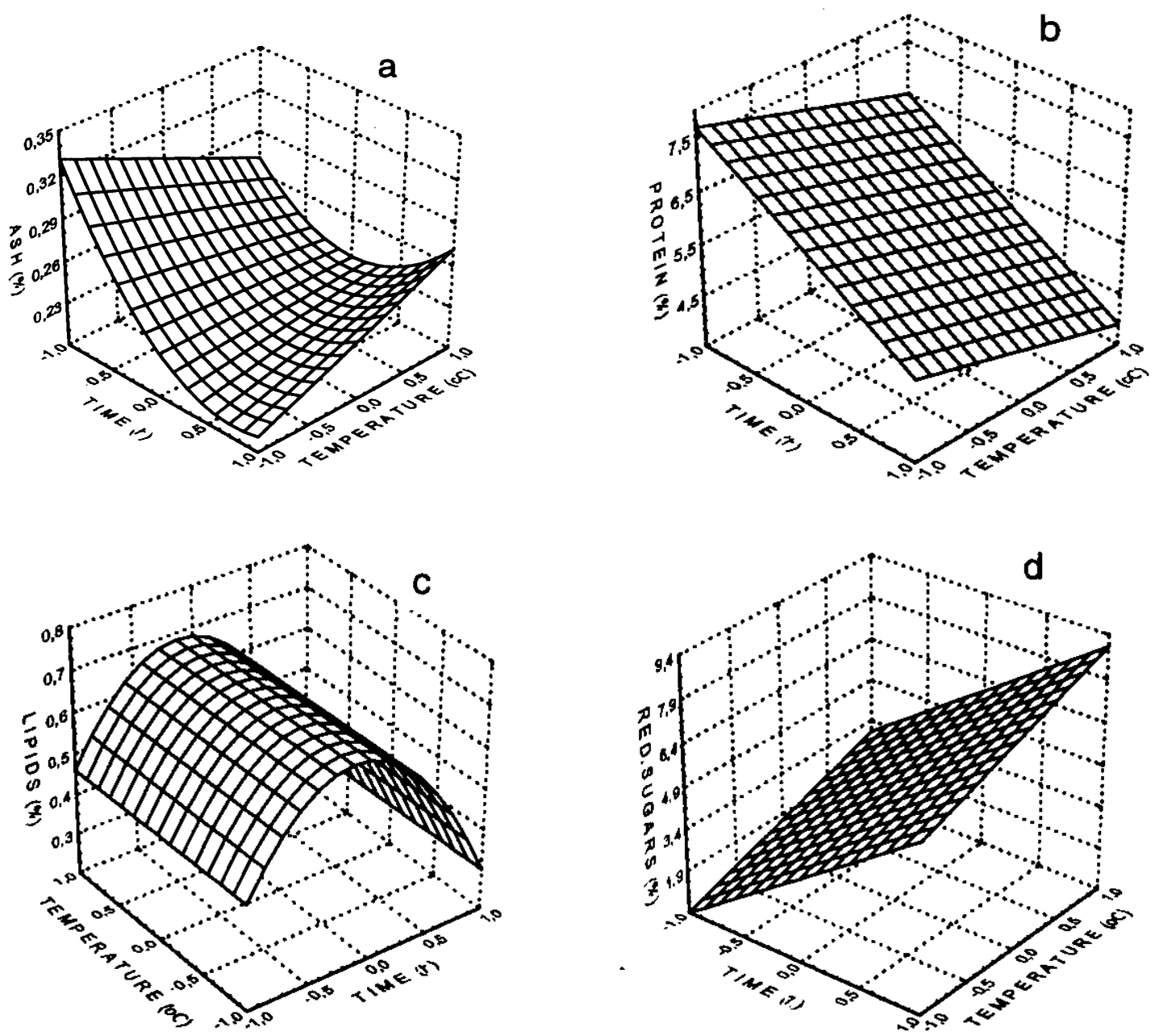

Fig.1. Effect of time and temperature of germination on chemical composition of corn flours:

(a) ash , (b) proteins, (c ) lipids and (d) reducing sugars.

The effects on WAI (Fig. 2b) may be explained by the same factors although, in this case, other factors should also be considered. The WAI decreased with the increase in germination time up to the fourth day, increasing subsequently. The effect of temperature was not significant. Lorenz et al (1983) and Lukov \& Bushuk (1984) justified the decrease of the WAI by the gradual loss of water retention capacity of proteins, as consequence of proteases action. On the other hand, Lorenz \& Kulp (1981), which observed an increase of starch WAI after longer periods of germination, attributed this phenomenon to amylases action in crystalline regions of the granule, increasing hygroscopicity. Other factor that probably contributed to the increase of WAI was the flour particle size, which decreased with germination time (data not presented), as a consequence of higher fragility of kernel. The decrease in flours viscosity induced by germination (Fig. 3 a, b) is desirable for preparation of weaning foods. Both peak viscosity (Fig. 3a) and cold viscosity (Fig. 3b) decreased with the increase in time up to the third day, remaining stable subsequently.

The decrease of viscosity is a consequence of $\alpha$ amilases action both during germination and during amylograph test, acting on the granules already more susceptible to their action. The higher fragility of granules also contribute to an easier breakdown, under mechanic agitation.Since low viscosity is the main desirable property, this may be achieved germinating the corn kernels at temperatures of $20-25^{\circ} \mathrm{C}$ for 3 days. Under these conditions a higher level of proteins is preserved, which is of nutritional interest. 

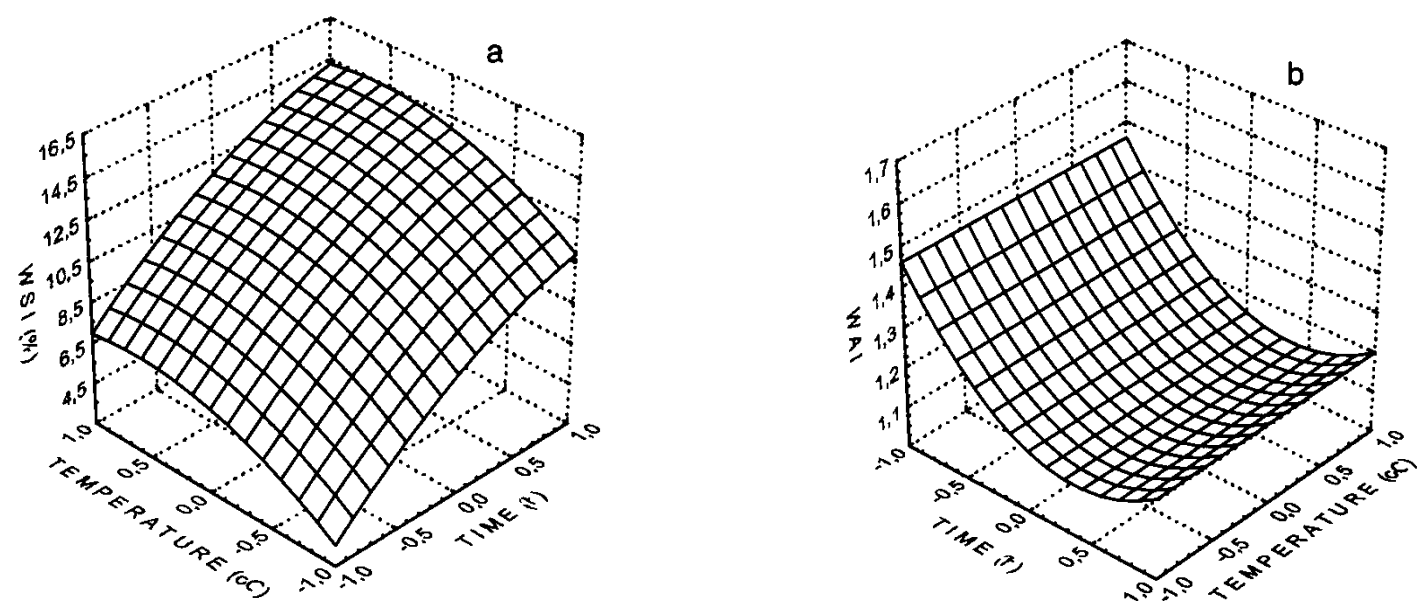

Fig. 2. (a) Water solubility index (\%) and (b) water absorption index (g gel / g sample) of corn flours as a function of time and temperature of germination.
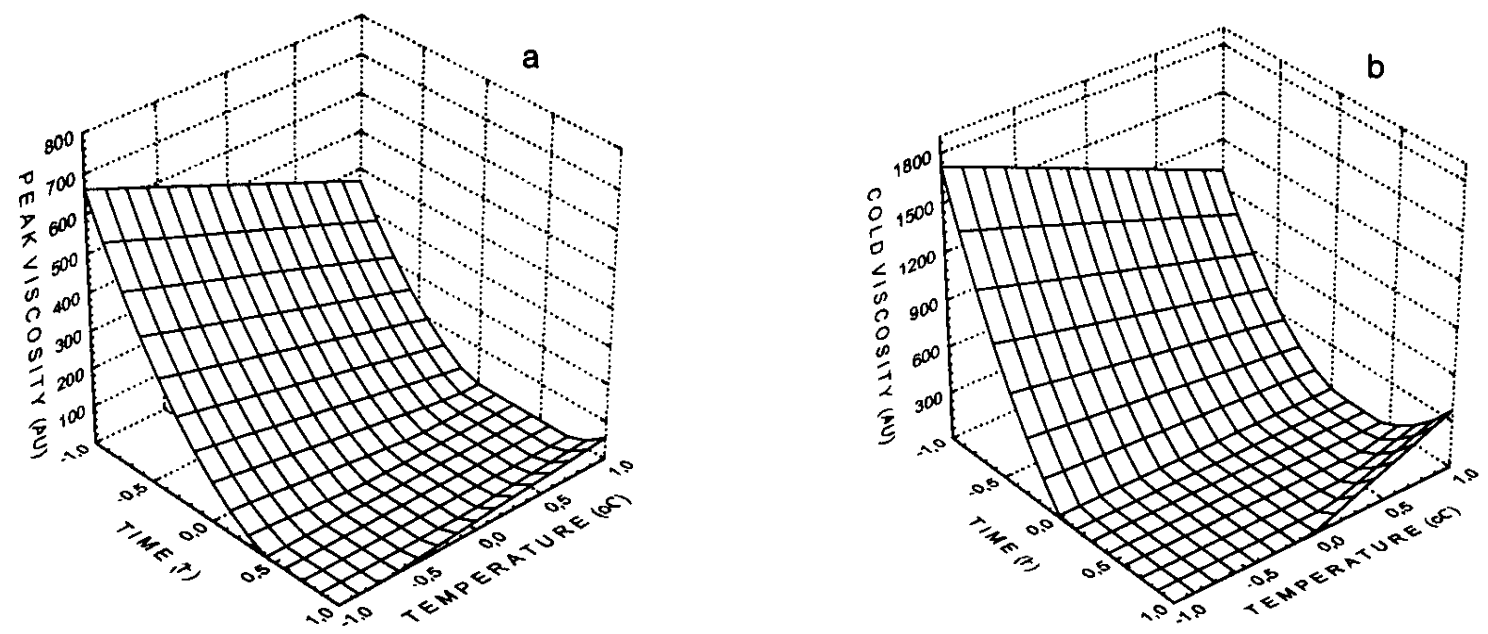

Fig.3. Effect of time and temperature of germination on : (a) peak viscosity and (b) cold viscosity. $\mathrm{AU}=$ Amylographic units

\section{CONCLUSION}

It is possible to produce corn flours with different physicochemical and functional properties using germinated corn kernels. Functional changes are consequence of biochemical modifications and weakening of grain also. The modified flours may have different industrial and food uses, mainly when products with high solubility and low viscosity are desired.

In order to obtain low viscosity and high water absorption index without high losses of proteins temperatures from 20 to $25^{\circ} \mathrm{C}$ for 3 days are recomended. Only when an increase in the WSI is desired, the corn kernels should be germinated for a longer period (4 - 5 days).

\section{RESUMO}

Farinhas com diferentes propriedades físicoquímicas e funcionais foram obtidas do milho maltado. Metodologia de Superfície de Resposta (RSM) foi usada para estudar os efeitos do tempo de maltagem $(1,3,5$ dias), temperatura de maltagem $\left(20,25,30^{\circ} \mathrm{C}\right)$ e concentração de ácido giberélico $(0.0 ; 0.5 ; 1.0 \%)$ nestas propriedades. A composição química e a viscosidade da pasta de farinha foram significativamente afetada pelo tempo e temperatura de maltagem, enquanto o índice de solubilidade em água (water solubility index - 
WSI) e índice de absorção de água (WAI) variou apenas com o tempo de maltagem. O ácido giberélico não influenciou significativamente nenhuma das propriedades estudadas. Germinação a $20-25^{\circ} \mathrm{C}$ por 3 dias foi recomendada para obter farinha de milho com alto índice de absorção de água (WAI), baixa viscosidade e médio índice de solubilidade em água (WSI), sem excessiva perda de proteínas.

\section{REFERENCES}

American Association of Cereal Chemists. (1983), Approved Methods of the AACC. The Association, St. Paul.

Anderson, R. A.; Pfeifer, V. F. \& Griffin, E. L. (1969), Gelatinization of corn grits by roll and extrusion cooking. Cereal Sci. Today, 14, 4-7.

Atwell, W. A.; Hyldon, R. G.; Godfrey, P.D.; Galle, E. L.; Sperber, W. H.; Pedersen, D.C.; Evans, W. D. \& Rabe, G. O. (1988), Germinated quinoa flour to reduce the viscosity of starchy foods. Cereal Chem., 65, 508-509.

Box, G. E. P. \& Behnken, D. W. (1960), Some new three level designs for the study of quantitative variables. Technometrics, 2 , 455-475.

Colmenares de Ruiz, A. S. \& Bressani, R. (1990), Effect of germination on the chemical composition and nutritive value of amaranth grain. Cereal Chem., 67, 1922.

Lorenz, K. (1980), Cereal Sprouts: Composition, Nutritive Value, Food Applications. CRC Critical Reviews in Food Science and Nutrition, 13, 353-385.

Lorenz, K. \& Kulp, K. (1981), Sprouting of cereal grains - Effects on starch characteristics. Starch, 33, 183-187.

Lorenz, K.; Roewe-Smith, P.; Kulp, K. \& Bates, L. (1983), Preharvest sprouting of winter
wheat.II. Aminoacid composition and functionality of flour and flour fractions. Cereal Chem., 60, 360-366.

Lukow, O. M. \& Bushuk, W. (1984), Influence of germination on wheat quality, I. Functional and biochemical properties. Cereal Chem., 61, 336-339.

Mora-Escobedo, R.; Paredes-Lopes, O. \& Gutierrez-Lopes,G. F. (1991), Effect of germination on the rheological and functional properties of amaranth seeds. Lebensmittel - Wissenschaft und Technol., 24, 241-244.

Mosha, A. C. \& Svanberg., V. (1983), Preparation of weaning foods with high nutrient density using flour of germinated cereals. Food Nutr. Bull., 5, 10.

Singh, T. \& Bains, G. S. (1984), Malting of corn: effect of variety, germination, gibberellic acid and alkali pretreatments. $J$. Agric. Food Chem., 32, 346-348,.

Statistical Analyses System. (1985), Sas User's Guide: Stastistics. 5 ed., Cary.

Tsai, C. Y.; Dalby, A. \& Jones, R. A. (1975), Lysine and tryptophan increases during germination of maize seed. Cereal Chem., 52, 356-360.

Pyler, R. E. \& Thomas, D. A. (1991), Malted Cereals: Production and Use. In: Handbook of Cereal Science and Technology, ed. K. J. Lorenz \& K. Kulp. New York: Marcel Dekker Inc., 815-832.

Waszczynskyj, N.; Rao, C. S. \& Silva, R. S. S. F. (1981), Extraction of proteins from wheat bran: application of carbohydrases. Cereal Chem., 58, 264-266.

Received: December 17, 1997 Revised: May 26, 1998; Accepted: July 28, 1998. 